\title{
Correction to: Ambient Air Temperature, Air Quality and the Timing of Excess Mortality Among Young Men in the United States
}

\author{
Robert Bozick ${ }^{1}[0$
}

Published online: 1 December 2021

(c) Springer Science+Business Media, LLC, part of Springer Nature 2021

Correction to: Human Ecology (2021)

https://doi.org/10.1007/s10745-021-00284-3

Table 2 of the original publication contains missing data. The original article has been corrected.

Publisher's Note Springer Nature remains neutral with regard to jurisdictional claims in published maps and institutional affiliations.

Robert Bozick

rbozick@rice.edu

1 Rice University, Houston, TX, USA 